\title{
Reinforced Concrete Buildings with Plane Frame, Shear Wall with and without Openings
}

\author{
Zafarullah Nizamani ${ }^{1 *}$, Wong Che Luk $^{1}$ and Syed Muhammad Bilal Haider ${ }^{1}$ \\ ${ }^{1}$ Faculty of Engineering and Green Technology, Universiti Tunku Abdul Rahman, Jalan Universiti, \\ Bandar Barat, 31900 Kampar, Perak, Malaysia
}

\begin{abstract}
Malaysia is situated at Sunda plate which has geographic advantage in seismic zone. However, an earthquake occurred in Sabah, east of Malaysia without a warning in 2015. This scenario raised the question regarding the structural performance of high-rise buildings in Malaysia in response to seismic activity. This study is to analyze the effects of the shear wall on seven RC buildings by using pushover analysis. This pushover analysis is a simple approach where a building is subjected to increasing horizontal lateral loads until the building fails. SCIA Engineer software is used to model three different designs of seven storeys buildings are model in accordance with the Eurocode 8. The pushover analyses are carried out on three models, pushover curves (base shear vs. roof displacement) are plotted, and they are compared to explore both elastic and inelastic properties of the building response to the seismic action. The frame model without shear wall can resist less base shear. The plane frame model also approaches maximum allowable displacement of $60 \mathrm{~mm}$ earlier as compared to the other two models. Therefore, the high-rise buildings with shear wall design are highly recommended for the lifelong seismic resistance of reinforced concrete buildings.
\end{abstract}

\section{Introduction}

Shear wall is the most important structural component in high-rise building especially for the building that is located in seismic zone. This is proven by tall buildings with proper shear walls design have better performances in past seismic responses. However, shear walls in earthquake zones required special detailing. Besides that, the stiffened shear walls also have high resistance in the combination of axial load, gravity force, moment, lateral load and shear. These forces are transferred to the foundation of the building. The lateral loads are wind load and earthquake load that have a tendency to damage structural and nonstructural elements. It also effectively reduces construction cost when shear walls are introduced to the high-rise building in the long run [1].

\footnotetext{
* Corresponding author: zafarullah@utar.edu.my
} 


\section{Literature review}

Most of the external frame of the tall building like apartment and business office usually consists of opening doors or windows. These openings at shear wall also one of the major factors which affect seismic responses. Furthermore, the unsymmetrical arrangement of the openings along the shear wall should be avoided and therefore the shear wall has sufficient strength to resist earthquake forces. Moreover, shear walls often symmetrically located at the exterior of building to reduce chances of the building from twisting.

Generally, every country has its national code of practice or annexure to code because the code contains design requirement within the construction industry. In Malaysia, the Eurocode is being followed but British Standard (BS) is still used as the reference for the code of practice. EC2 and BS 8110 are a design code for concrete structures widely in Malaysia. The Malaysia Standard Codes of Practice (MSCP) for the structural use of concrete, MS EN 1992 is developed through the adoption of EC 2 [2].

Shear wall systems can be advantageous in many structural engineering applications in term of resisting lateral forces. When the shear walls have enough stiffness, they are capable to transfer horizontal forces to other components of buildings most likely include other shear walls, floors, foundation walls, and slabs. Besides that, shear walls can also prevent excessive side sway of roof or floor as they provide a significant amount of stiffness due to lateral forces. Next, they also help to maintain a strong connection between floor and roof frame members from its supports. Other than structural damage level, nonstructural member damage within building such as indoor facilities, windows, door, and others can be minimized [3].

Pushover analysis is classified as a nonlinear static approach. Generally, this analysis method can be carried out under constant gravity loads and an increasing lateral forces which is subjected to structural model leading inertia forces that induced by the seismic action. As the applied lateral force is not fixed and increases monotonically, the method can be useful to describe the plastic mechanism of the model includes the ultimate load and maximum of inelastic deflection to verify structural performance. The pushover analysis is a method to identify the stage of successive structural damage [4-5]. According to EC 8, there is mainly two type of lateral load pattern include uniform pattern and modal pattern. Both patterns are performed to run the nonlinear pushover analysis.

\section{Methodology}

Figures 1-3 show three different design models of a seven storey building are modelled using the software SCIA Engineer V15. The outline plan of the three square shaped models is $22.5 \mathrm{~m}$ width and $22.5 \mathrm{~m}$ length are shown in Figure 1-3. Figure 4 is the plan view of the buildings. Figure 1 is plane frame structural system with beam column system and without a shear wall. The other two models, as shown in Figure 2 - 3 are the shear wall with and without holes. The model is shown in Figure 2 and is designed with $7.5 \mathrm{~m}$ width and 22.5 $\mathrm{m}$ height of shear wall placed at outer edge parallel to $\mathrm{X}$ and $\mathrm{Y}$-directions. Model in Figure 3.3 is almost similar to Figure 3, the only difference is that this model has $0.5 \mathrm{~m} \times 1.0 \mathrm{~m}$ of openings in each storey of the shear wall. These three models are designed in compliance with EC 8, the design of structures for earthquake resistance. Table 1 shows the section of the structural elements of the building. Typically, all storeys of the building have constant three meters height except ground floor which is five meters. 
Table 1. Details of the Frame structure

\begin{tabular}{|l|l|}
\hline No of storeys & 7 \\
\hline Number of Grid Lines in X - Direction & 4 \\
\hline Spacing of Grids in Y - Direction (m) & 7.5 \\
\hline Bottom storey height (m) & 5.0 \\
\hline Typical storey height (m) & 3.0 \\
\hline
\end{tabular}

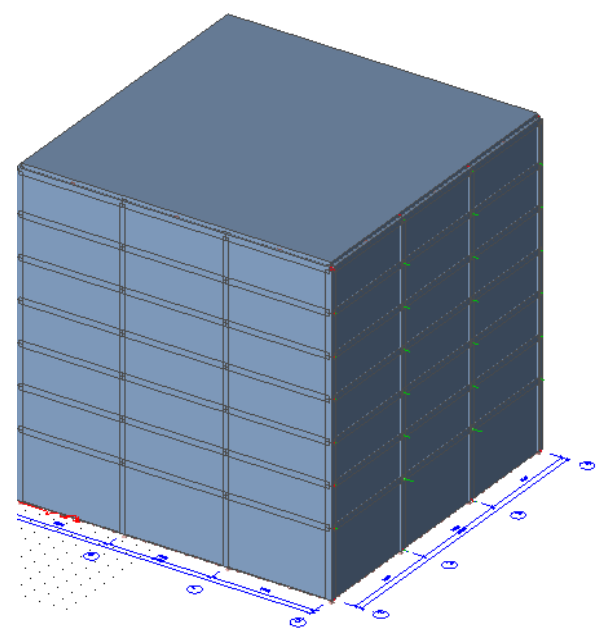

Fig. 1. Seven Storey Bare Model without Shear Wall

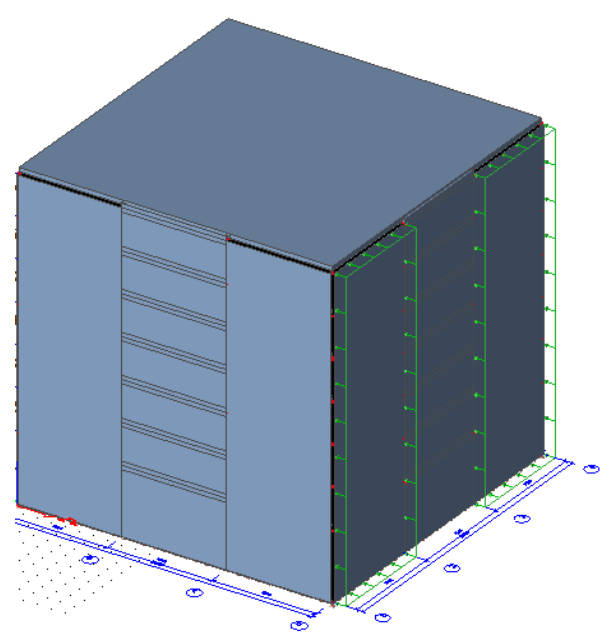

Fig. 2. Seven Storey Model with Shear Wall without openings. 


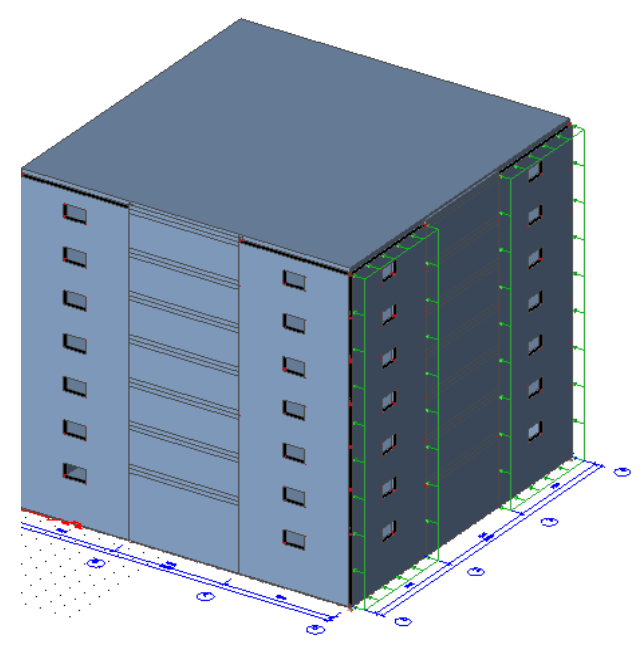

Fig. 3. Seven Storey Plane frame Model with Openings at Shear Wall

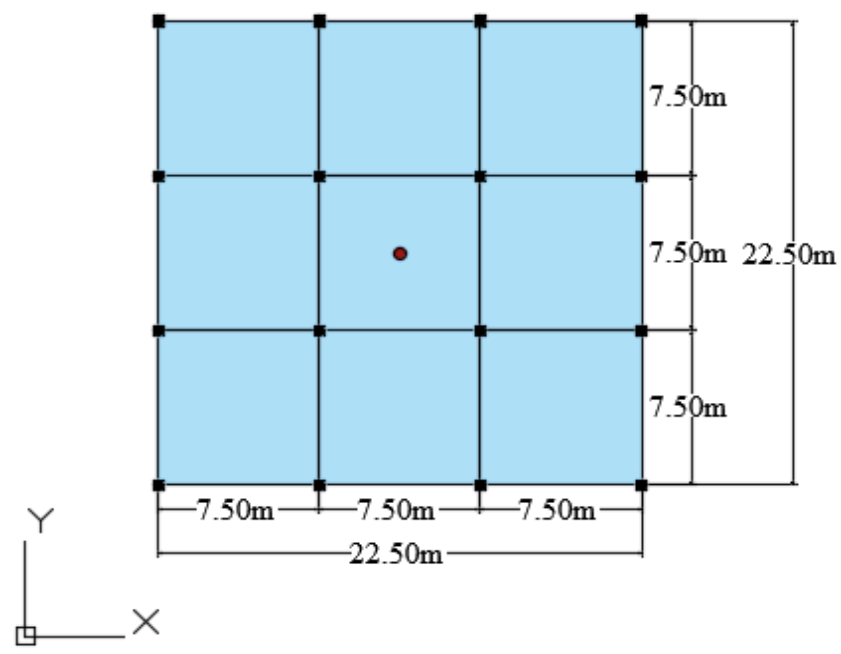

Fig. 4. Typical Building Plan

\section{Results and discussion}

The results of nonlinear pushover analysis together with the deformed structure using three different structural models are presented here. The first model is plane frame structural system while the other two models are the dual type of structural systems. The dual system means not frames are used only, however, the shear walls also introduced to the structural building system.

Since three of the models are satisfied with the criterions of structural regularity or symmetrical in the floor plan, therefore, the pushover load is applied in one direction, i.e., negative $\mathrm{X}$ only. This is due to its symmetrical floor plan characteristic of the models. Thus, it is expected that the result is similar when the pushover analysis is applied in negative Y-direction. 
According to American Society of Civil Engineers (ASCE), the maximum allowable displacement or drift for building less than four storeys and more than five storeys are $2.5 \%$ and $2 \%$ of the top height of storey respectively. In this study, all of the models are designed in a total of seven storeys and top (seventh) storey has three-meter height. Therefore, the maximum allowable displacement on top roof is about $60 \mathrm{~mm}$. Figure 5 shows a total number of four nodes are recorded at roof area because these nodes are most critical nodes that will deform under seismic action when the pushover analysis is performed.

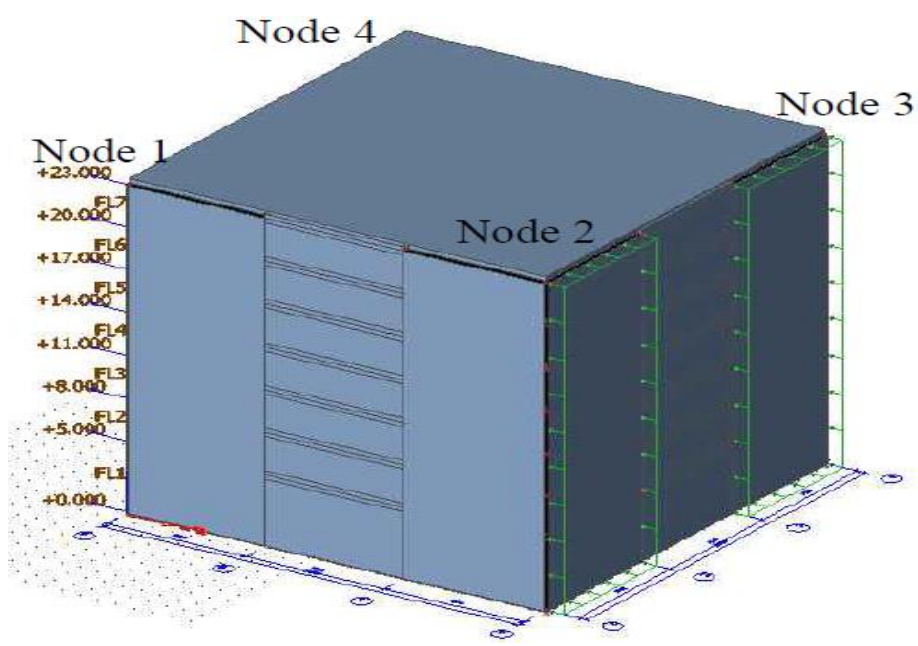

Fig. 5. Four Nodes Labelled at Top Roof of the Buildings

\subsection{Base shear versus roof displacement}

Table 2 shows the base shear of the model for negative X-direction is $699 \mathrm{MN}$ with roof displacement of four nodes are recorded. It is found that all of the nodes exceed the maximum allowable roof displacement of $60 \mathrm{~mm}$; however, node 3 has the highest drift, which is $67.2 \mathrm{~mm}$. Based on the result in Table 1, a pushover curve of base shear versus roof displacement with a failure point is plotted as shown in Figure 6. The failure point is a point where the roof of the model approaches the maximum allowable displacement. With the help of Microsoft Excel, the equation of the pushover curve can use to determine the failure point by using the interpolation method. 
Table 2. Base Shear \& Roof Displacement of Plane frame Model by Nonlinear

Pushover Analysis at Negative X-Direction

\begin{tabular}{|l|l|l|l|l|l|}
\hline \multirow{2}{*}{$\begin{array}{l}\text { Lateral } \\
\text { load } \\
\left(\mathbf{k N} / \mathbf{m}^{2}\right)\end{array}$} & \multirow{2}{*}{$\begin{array}{l}\text { Base shear (thousand } \\
\mathbf{k N})\end{array}$} & \multicolumn{4}{|c|}{ Displacement of roof (mm) } \\
\cline { 3 - 6 } & 776 & node 1 & node 2 & node 3 & node 4 \\
\hline 1 & 1553 & 0.0 & 0.1 & 0.1 & 0.0 \\
\hline 2 & 2329 & 0.1 & 0.2 & 0.2 & 0.1 \\
\hline 3 & 3105 & 0.2 & 0.2 & 0.3 & 0.2 \\
\hline 4 & 3881 & 0.2 & 0.3 & 0.3 & 0.2 \\
\hline 5 & 4658 & 0.3 & 0.4 & 0.4 & 0.3 \\
\hline 6 & 5434 & 0.4 & 0.5 & 0.5 & 0.4 \\
\hline 7 & & 0.4 & 0.5 & 0.6 & 0.5 \\
\hline 600 & 465750 & & & & \\
\hline 700 & 543375 & 41.8 & 42.5 & 44.8 & 42.5 \\
\hline 800 & 621000 & 48.8 & 49.5 & 52.3 & 49.6 \\
\hline 900 & 698625 & 55.8 & 56.6 & 59.7 & 56.7 \\
\hline
\end{tabular}

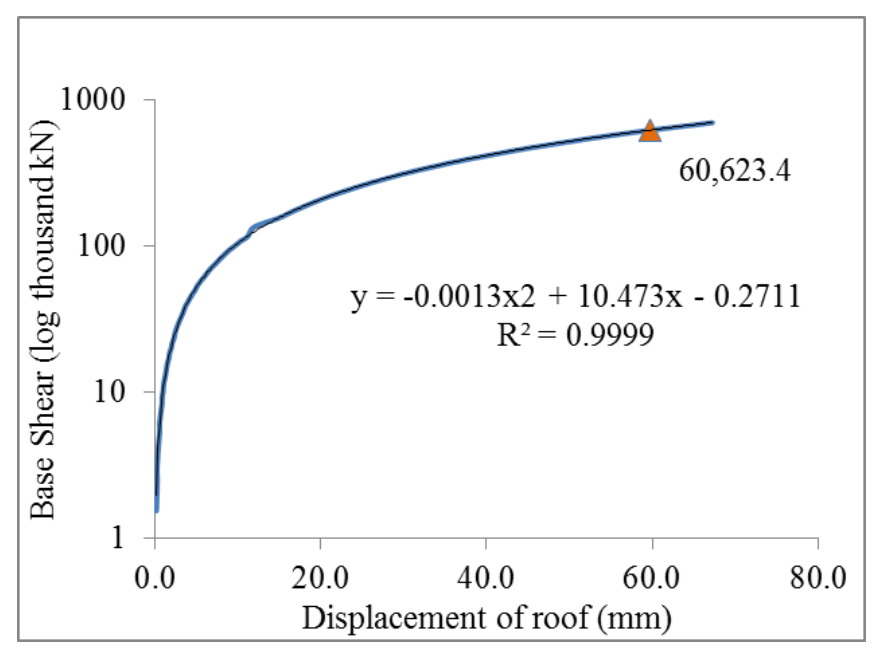

Fig. 6. Pushover Curve for Plane frame Modal

Table 3 shows the base shear of the model for negative X-direction with roof displacement of four nodes is recorded. It is found that node 2 and node 3 exceed the maximum allowable roof displacement of $60 \mathrm{~mm}$ where both nodes have $62.9 \mathrm{~mm}$ roof displacement at the base shear of $673 \mathrm{MN}$. A pushover curve of base shear versus roof displacement with a failure point of the particular model is plotted as shown in Figure 7. 
Table 3. Base Shear \& Roof Displacement of Model with Shear Wall by Nonlinear

Pushover Analysis at Negative X-Direction

\begin{tabular}{|c|c|c|c|c|c|}
\hline \multirow{2}{*}{$\begin{array}{l}\text { Lateral } \\
\text { load } \\
\left(\mathbf{k N} / \mathbf{m}^{\mathbf{2}}\right)\end{array}$} & \multirow{2}{*}{$\begin{array}{l}\text { Base } \\
\text { (thousand kN) }\end{array}$} & \multicolumn{4}{|c|}{ Displacement of roof (mm) } \\
\cline { 3 - 6 } & & node 1 & node 2 & node 3 & node 4 \\
\hline 0 & 0 & 0.0 & 0.0 & 0.0 & 0.0 \\
\hline 1 & 518 & 0.0 & 0.1 & 0.1 & 0.0 \\
\hline 2 & 1035 & 0.1 & 0.1 & 0.1 & 0.1 \\
\hline 3 & 1553 & 0.1 & 0.2 & 0.2 & 0.1 \\
\hline 4 & 2070 & 0.1 & 0.2 & 0.2 & 0.1 \\
\hline 5 & 2587 & 0.2 & 0.3 & 0.3 & 0.2 \\
\hline 6 & 3105 & 0.2 & 0.3 & 0.3 & 0.2 \\
\hline 7 & 3623 & 0.3 & 0.4 & 0.4 & 0.3 \\
\hline 600 & 310500 & 28.1 & 29.1 & 29.1 & 28.1 \\
\hline 700 & 362250 & 32.8 & 33.9 & 33.9 & 32.8 \\
\hline 800 & 414001 & 37.5 & 38.7 & 38.7 & 37.5 \\
\hline 900 & 465750 & 42.2 & 43.6 & 43.6 & 42.2 \\
\hline 1000 & 517500 & 46.9 & 48.4 & 48.4 & 46.9 \\
\hline 1100 & 569250 & 51.6 & 53.3 & 53.3 & 51.6 \\
\hline 1200 & 621000 & 56.3 & 58.1 & 58.1 & 56.3 \\
\hline 1300 & 672750 & 61.0 & 62.9 & 62.9 & 61.0 \\
\hline
\end{tabular}

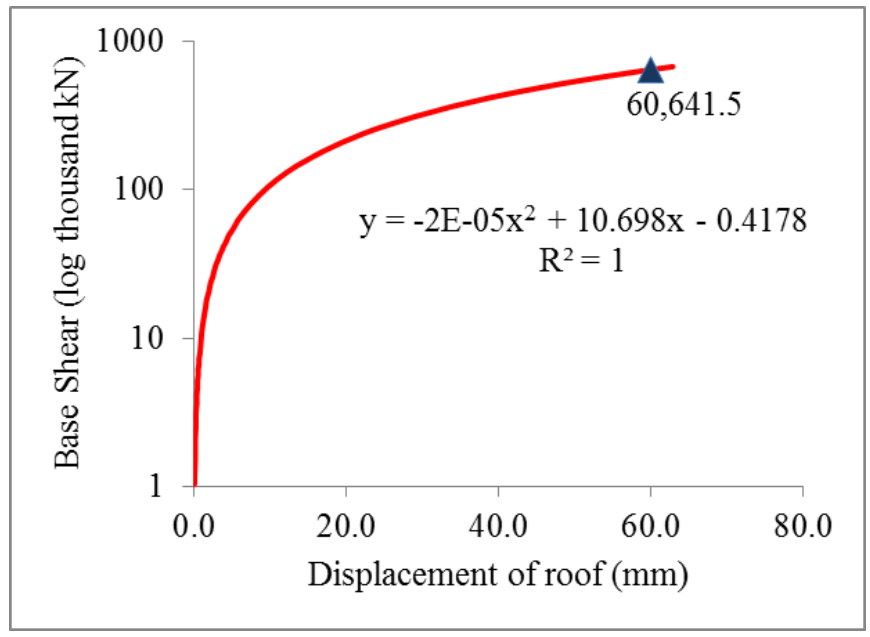

Fig. 7. Pushover Curve for Modal with Shear Wall 
Table 4 represents the base shear and roof displacement of four nodes of the model with openings at the shear wall for negative X-direction. It is also found that node 2 and node 3 exceed the maximum allowable roof displacement of $60 \mathrm{~mm}$ where both have $60.5 \mathrm{~mm}$ displacement at top roof. Based on the results in Table 4, a pushover curve of base shear versus roof displacement with a failure point is plotted as shown in Figure 8.

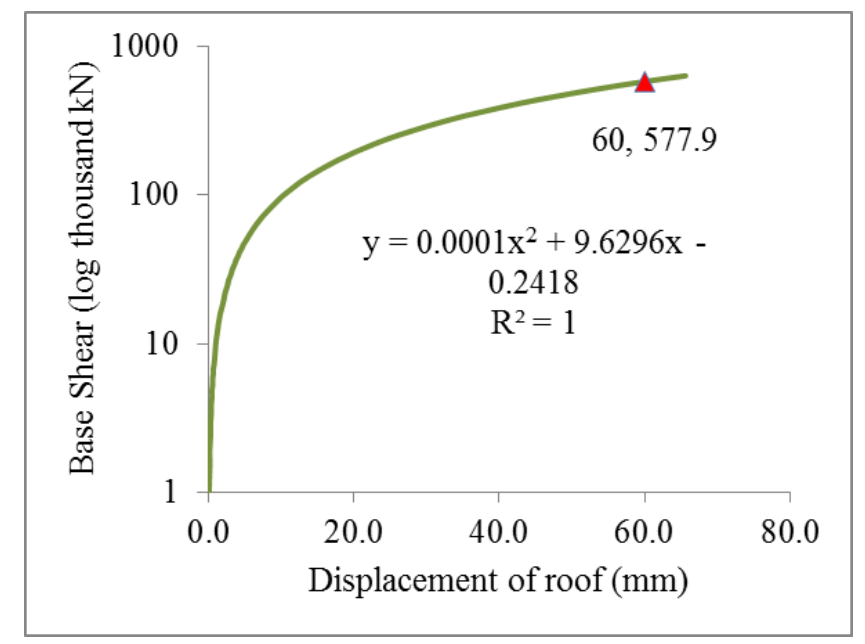

Fig. 8. Pushover Curve for Modal with Openings at Shear Wall 
Table 4. Base Shear \& Roof Displacement of Model with Openings at Shear Wall by Nonlinear Pushover Analysis at Negative X-Direction

\begin{tabular}{|c|c|c|c|c|c|}
\hline \multirow{2}{*}{$\begin{array}{l}\text { Lateral load } \\
\left(\mathbf{k N} / \mathbf{m}^{\mathbf{2}}\right)\end{array}$} & \multirow{2}{*}{$\begin{array}{c}\text { Base } \\
\text { (thousand } \mathbf{k N})\end{array}$} & \multicolumn{4}{|c|}{ Displacement of roof (mm) } \\
\cline { 3 - 6 } & $\mathbf{n o d e} \mathbf{1}$ & node 2 & node 3 & node 4 \\
\hline 0 & 0 & 0.0 & 0.0 & 0.0 & 0.0 \\
\hline 1 & 486 & 0.0 & 0.1 & 0.1 & 0.0 \\
\hline 2 & 972 & 0.1 & 0.1 & 0.1 & 0.1 \\
\hline 3 & 1458 & 0.1 & 0.2 & 0.2 & 0.1 \\
\hline 4 & 1944 & 0.2 & 0.2 & 0.2 & 0.2 \\
\hline 5 & 2430 & 0.2 & 0.3 & 0.3 & 0.2 \\
\hline 6 & 2916 & 0.3 & 0.3 & 0.3 & 0.3 \\
\hline 7 & 3402 & 0.3 & 0.4 & 0.4 & 0.3 \\
\hline 600 & 291600 & 29.4 & 30.3 & 30.3 & 29.4 \\
\hline 700 & 340200 & 34.3 & 35.3 & 35.3 & 34.3 \\
\hline 800 & 388800 & 39.2 & 40.4 & 40.4 & 39.2 \\
\hline 900 & 437400 & 44.1 & 45.4 & 45.4 & 44.1 \\
\hline 1000 & 486000 & 49.0 & 50.5 & 50.5 & 49.0 \\
\hline 1100 & 534600 & 53.9 & 55.5 & 55.5 & 53.9 \\
\hline 1200 & 583200 & 58.8 & 60.5 & 60.5 & 58.8 \\
\hline 1300 & 631800 & 63.7 & 65.6 & 65.6 & 63.7 \\
\hline
\end{tabular}

The plane frame model which means the building designed without shear wall fails after $900 \mathrm{kN} / \mathrm{m}^{2}$, however, the model shear wall fails after $1300 \mathrm{kN} / \mathrm{m}^{2}$ and the third model where openings at shear wall fail after $1200 \mathrm{kN} / \mathrm{m}^{2}$. This can be explained theoretically, the shear wall at second and third model have higher resistance to seismic load compared to plane frame model building which resists lateral load at beam and column only.

\section{Conclusion}

The plane frame model can resist lesser base shear than the model with the shear wall. Next, the plane frame model also approaches maximum allowable displacement of $60 \mathrm{~mm}$ at the first place compared to other models. Apart from that, the model with the shear wall has the least displacement of roof followed by, the model with openings at the shear wall and then the plane frame model when $900 \mathrm{kN} / \mathrm{m}^{2}$ of lateral pushover loads are applied. These results show that existence of shear wall has increase seismic performance of highrise building.

This material is based upon work supported by the Universiti Abdul Rahman (UTAR) under Grant No. IPSR/RMC/UTARRF/2016-C1/Z1 


\section{References}

1. Harne, V. 2014. Comparative Study of Strength of RC Shear Wall at Different Location on Multi-storied Residential Building. International Journal of Civil Engineering Research. 5(4), pp.391-400.

2. Meher, M. and Muthumani, K. (2016). Lateral seismic response of framed structure with shear wall. International Journal of Engineering and Management Sciences. 7(3), pp. 214-220.

3. Murty, C. V. R. 2015. Why are Buildings with Shear Walls preferred in Seismic Regions? Kanpur: Building Materials and Technology Promotion Council (BMTPC), p. 2.

4. Ng, M. K. 2007. The Strategy of Implementing Eurocode 2 in Malaysia. Master. Universiti Teknologi Malaysia.

5. Santhosh, D. 2014. Pushover Analysis of RC Frame Structure using ETABS 9.7.1. IOSR Journal of Mechanical and Civil Engineering (IOSR-JMCE). 11(1), pp. 0816. 